\title{
MEASURING AND COMPARING THE WATER ACTIVITY AND SALT CONTENT IN PARENICA CHEESES MADE BY TRADITIONAL AND INDUSTRIAL TECHNOLOGY
}

\author{
Lucia Zeleňákovál, Michal Ševčík², Silvia Jakabovál, Peter Zajác ${ }^{l}$, \\ Margita Čanigová ${ }^{3}$, Marta Habánová, Joanna Wyka
}

${ }^{1}$ Slovak University of Agriculture, Faculty of Biotechnology and Food Sciences, Department of Food Hygiene and Safety, Tr. A. Hlinku 2, 94976 Nitra, Slovak Republic

${ }^{2}$ Constantine the Philosopher University in Nitra, Department of Ecology and Environmental Science,

Tr. A. Hlinku 1, 94974 Nitra, Slovak Republic

${ }^{3}$ Slovak University of Agriculture, Faculty of Biotechnology and Food Sciences, Department of Technology and Quality of Animal Products, Tr. A. Hlinku 2, 94976 Nitra, Slovak Republic

${ }^{4}$ Slovak University of Agriculture,Faculty of Agrobiology and Food Resources, Department of Human

Nutrition, Tr. A. Hlinku 2, 94976 Nitra, Slovak Republic

${ }^{5}$ Wroclaw University of Environmental and Life Sciences Department of Human Nutrition,

Chełmońskiego 37, 51-630 Wrocław, Poland

\begin{abstract}
Background. Slovenská Parenica is one of the most traditional and ever-popular sheep's milk cheese specialities. This cheese has been registered as a geographical indication (PGI) in the EU. Parenica cheese is produced also from cow's milk, but without the trade name "Slovenská/Slovak".

Objective. The aim of our research was was statistical reporting and results visualization of water activity analysis and salt content in cow's milk Parenica cheeses from 8 small and medium-sized Slovak dairy producers.

Material and method. A total of 320 samples of smoked and non-smoked Parenica cheeses made from cow's milk using traditional and industrial technology were examined during the 10-month period. Each cheese was analysed immediately after sampling (A) and subsequently after 7 days of storing at $4^{\circ} \mathrm{C}(\mathrm{B})$. The salt content was measured on the Chloride analyser M 926 and the water activity on the Fast-Lab meter. Due to the hierarchical design of the experiment, the linear mixed models via the R statistical environment to compare the differences in the water activity and salt content were used. Results. Statistical reporting and visualization of water activity measurements showed significant differences between samples A and B $(p=0.0129)$ and between kinds of Parenica cheese $(p=0.0196)$. The value of water activity ranged from 0.908 to 0.975 (A) with the increasing trend after storing in both kinds of Parenica cheese. The impact of dairy producer type was not significant. The higher content of $\mathrm{NaCl}$ was found in fresh Parenica cheese from small farms (nonsmoked: $2.51 \pm 1.12 \mathrm{~g} / 100 \mathrm{~g}$, smoked: $1.97 \pm 0.89 \mathrm{~g} / 100 \mathrm{~g}$ ). The average salt content in cheeses from industrial dairies was $1.65 \pm 0.34 \mathrm{~g} / 100 \mathrm{~g}$ (non-smoked) and $1.96 \pm 0.43 \mathrm{~g} / 100 \mathrm{~g}$ (smoked). Results showed lower variability of salt content in cheeses from industrial dairies.

Conclusions. It can be concluded that especially the small producers can have probably problem in noncompliance with the technological processes, non-implementation of standardized procedures and underestimation of hygiene regulations.
\end{abstract}

Key words: Parenica cheese, salt, water activity, dairies, statistical models

\section{STRESZCZENIE}

Wprowadzenie. „Słowacka Parenica” to jeden z tradycyjnych i bardzo popularnych serów wytwarzanych z owczego mleka. Produkt ten został zarejestrowany w systemie ochrony regionalnych produktów rolnych (PGI) przez Unię Europejską. Ser „Parenica” produkowany jest również w wersji z mleka krowiego, ale bez nazwy „słowacka”.

Cel. Celem naszych badań było oznaczenie i porównanie aktywności wody i zawartości soli w serach „Parenica” pochodzących z 8 małych i średnich słowackich producentów mleka.

Material i metoda. W ciągu 10 miesięcy zbadano ogółem 320 próbek wędzonych i niewędzonych serów Parenica wytworzonych z mleka krowiego przy użyciu technologii tradycyjnej i przemysłowej. Analizowano sery zaraz po pobraniu

Corresponding author: Lucia Zeleňáková, (ORCID: https://orcid.org/0000-0003-1387-7410) Slovak University of Agriculture, Faculty of Biotechnology and Food Sciences, Department of Food Hygiene and Safety, Tr. A. Hlinku 2, 94976 Nitra, Slovak Republic, e-mail: lucia.zelenakova@uniag.sk 
próbki (A) oraz po 7 dniach przechowywania w temperaturze $4^{\circ} \mathrm{C}$ (B). Zawartość soli oznaczano na analizatorze chlorków M 926, a aktywność wody w aparacie Fast-Lab. Ze względu na hierarchiczną strukturę eksperymentu zastosowano liniowe modele mieszane w środowisku statystycznym R do porównania różnic w aktywności wody i zawartości soli.

Wyniki. Analizy statystyczne i wykresy pomiarów aktywności wody wykazały statystyczne różnice między próbkami A i B $(p=0.0129)$ oraz między rodzajami sera Parenica $(p=0.0196)$. Wartość aktywności wody wahała się w zakresie od 0.908 do 0.975 (A), wykazano trend wzrostowy tego parametru podczas przechowywania obu rodzajów sera Parenica. Nie stwierdzono statystycznych różnic pomiędzy poszczególnymi producentami serów. Wyższą zawartość NaCl stwierdzono w świeżym serze Parenica produkowanym w małych gospodarstwach (niewędzone $2.51 \pm 1.12 \mathrm{~g} / 100 \mathrm{~g}$, wędzone $1.97 \pm 0.89 \mathrm{~g} / 100 \mathrm{~g}$ ). Średnia zawartość soli w serach produkowanych przemysłowo wyniosła $1.65 \pm 0.34 \mathrm{~g} / 100 \mathrm{~g}$ (niewędzone) a $1.96 \pm 0.43 \mathrm{~g} / 100 \mathrm{~g}$ (wędzone). Badania wykazały mniejszą zmienność zawartości soli w serach z mleczarni przemysłowych.

Wnioski. Można stwierdzić, że szczególnie mali producenci mogą mieć trudności z utrzymywaniem standardów i ujednoliceniem procedury technologicznej oraz przestrzeganiem rezimu higienicznego podczas wytwarzania produktu.

Słowa kluczowe: ser Parenica, sól, aktywność wody, mleczarnie, modele statystyczne

\section{INTRODUCTION}

Traditional cheeses represent the heritage and are the result of accumulated empirical knowledge passed on from generation to generation. Every traditional cheese is connected to the territory of its origin and to the prevailing environmental conditions [5].

Among traditional cheeses are also steamed cheeses, which are characterized by a unique production. They usually have a flat-cylindrical shape, no holes, and straw-yellow to yellow colour. Traditional steamed cheeses are made from milk of cows, goats, sheep, or buffalo cows [36].

Steamed cheeses are currently produced in Slovakia and have received the status of 'Protected Geographical Indication' within the European Union. Products with this designation include e.g. Slovenská parenica [12], Oravský korbáčik [14], Zázrivský korbáčik [15], Slovenský oštiepok [13], Slovenská Parenica is a traditional Slovak cheese. The name comes from the Slovak word for steaming. Parenica is a soft, steamed cheese made from unpasteurized sheep's milk of the Wallachian, Cigaya, East Friesian, and improved Wallachian breeds. The cheese can also be made using a mixture of raw sheep's and cow's milk, where the content of sheep's milk must be at least $50 \%$. The fat content in the dry mater is at least $50 \%$ and the salt content should not exceed 3\% [9, 27, 28].

Slovenská Parenica is a steamed, lightly smoked or non-smoked cheese wound into two opposed rolls 0.06 $-0.08 \mathrm{~m}$ in diameter and $0.05-0.08 \mathrm{~m}$ high, forming „S“ shape bulk. Moreover, the rolls are bound with cheese string. Prior to rolled up, the cheese strips are $0.002-0.003 \mathrm{~m}$ thick, $0.05-0.08 \mathrm{~m}$ wide, and $4-$ $6 \mathrm{~m}$ long [10, 11, 24]. Cows' cheese version is also produced but without trade name Slovenská.

Salt plays an important role in cheese production. The salt addition has three basic functions: (1) acts as a preservative, (2) has an effect on cheese taste, and (3) is a source of sodium. The addition of salt further regulates the water content of the cheese, reduces the water activity, and affects the ripening $[3,36]$. Everett and Auty [19] reported that salt limits the action of bacteria in cheese, as well as has the secondary effect of flavor enhancement. Saltiness is one of the most important flavor attributes of cheese and is directly correlated to overall desirability by consumers.

The salt content of the product may be concentrated due to the gradual loss of water and increasing the dry matter content. This effect was observed by several authors $[8,18,25,40]$. $\mathrm{NaCl}$ influences cheese ripening principally through its effects on water activity. Among the principal effects of salt are control of microbial growth and activity; control of the various enzyme activities in cheese; syneresis of the curd and thus in a reduction in cheese moisture, which also influences the above; and physical changes in cheese proteins which influence cheese texture, protein solubility and probably protein conformation [21].

Water activity is a critical parameter that determines the shelf life of products. It is a very important measurement to maintain the chemical and microbiological stability of the food, to improve the shelf life of products. Measuring water activity enables us to predict which microorganism is or is not a potential source of spoilage. Most bacteria do not multiply at water activities below 0.91 and most moulds do not multiply below 0.80 [1]. The $\mathrm{a}_{\mathrm{w}}$ factor controlling the type and number of microorganisms in cheese plays a vital role in respect of safety and also affect the metabolic pathways leading to flavor development in steamed cheese [16]. Measuring the water activity is an important Critical Quality Control (CQC) step during cheese making as well as storing [45].

Each type of cheese may have a slightly different technological process and subsequent water activity level. It is important for manufacturers and companies to be aware of the differences and treat each cheese variety with the quality and care it deserves. Measuring $a_{w}$ of cheese essentially gives the manufacturer control of the cheese process [4]. 
In context with the above mentioned, the goal of this study was statistical reporting and visualization of results of water activity analysis and salt content in cow's milk Parenica cheeses from various Slovak dairy producers.

\section{MATERIAL AND METHODS}

Samples of fresh non-smoked and smoked Parenica cheeses made from cow's milk were analysed monthly during the 10-month period. Samples no. 2, 4, 5 and 7 were obtained directly from dairy producers of small size - farm dairy, other samples (no. 1, 3, 6 and 8 ) were taken from dairy producers of medium size - industrial dairy. The characteristics of analysed samples are given in the Table 1. $\mathrm{mg} / 1$ (milligrams per liter Chloride) or mg \% (milligrams percentage) salt as Sodium Chloride.

The water activity was analysed on the Fa-st lab apparatus (O.K. Service, BioPro). The water activity meter Fa-st lab uses the hygrometric technology that is also called dew point technology. During the measurement, the instrument shows the measurement time, the sample temperature, $a_{w}$ mean, and $a_{w}$ flash when a flash is activated. $a_{w}$ mean corresponds to the mean of the last 40 instantaneous measurements done during the last 20 seconds.

All chemicals and standards were analytical grade and obtained from Sigma Aldrich.

To compare dairy producers in terms of the consistency of salt content and water activity of their products, the coefficient of variation (cv) was used.

Table 1. Specification of the analysed smoked and non-smoked Parenica cheeses from Slovak dairies

\begin{tabular}{|c|c|c|c|}
\hline $\begin{array}{l}\text { Cheese } \\
\text { sample }\end{array}$ & Cow's milk & Cheese characteristics & Declared parameters \\
\hline 1 & pasteurized & semisoft, semi-skimmed & $\begin{array}{c}\text { dry matter: } \min .45 \% \\
\text { fat in dry matter: } 35 \% \\
\text { salt: } \max .2 .5 \%\end{array}$ \\
\hline 2 & non-pasteurized & semisoft, semi-skimmed & undeclared \\
\hline 3 & pasteurized & semisoft, semi-skimmed & $\begin{array}{c}\text { dry matter: } \min .46 \% \\
\text { fat in dry matter: } 40 \% \text {, } \\
\text { salt: } \max .2 \%\end{array}$ \\
\hline 4 & non-declared & soft, whole & undeclared \\
\hline 5 & pasteurized & Bio Parenica & $\begin{array}{c}\text { dry matter: min. } 41 \% \\
\text { fat in dry matter: } 45 \% \\
\text { salt: } \max .2 \%\end{array}$ \\
\hline 6 & pasteurized & semisoft, semi-skimmed & $\begin{array}{c}\text { fat in dry matter: } 37 \% \\
\text { salt: } \max .2 \%\end{array}$ \\
\hline 7 & non-pasteurized & semisoft, semi-skimmed & $\begin{array}{c}\text { fat in dry matter: } 45 \% \\
\text { salt: } \max .4 .5 \%\end{array}$ \\
\hline 8 & pasteurized & undeclared & $\begin{array}{c}\text { dry matter: } \min .35 \% \\
\text { fat in dry matter: } 44 \% \\
\text { salt: } \max .2 \%\end{array}$ \\
\hline
\end{tabular}

Analysis of salt content and the water activity were realized on the fresh cheese samples (A) and subsequently after 7 days of storing in the original packing at $4{ }^{\circ} \mathrm{C}$ (B). The expiration dates of the cheeses, listed by the producers, varied from 7 to 28 days. Together 320 cheese samples were analysed in triplicates.

The salt content (based on the chloride concentration) was measured on the Chloride analyser M 926 (O.K. Service, BioPro). It is an instrumental analog of "Argentometry", the traditional titrimetric methods using Silver Nitrate reagent. The analyser automatically titrates chloride ions by passing a known constant current between two silver electrodes which provides a constant generation of silver ions. The sample volume is $0.5 \mathrm{ml}$ and results are displayed on a digital readout in
The hierarchical configuration of the experiment required a multilevel model to analyse differences within the water activity and salt content. Statistical computing in $\mathrm{R}$ language [38] with using the nlme package [7] was used for these linear mixed models (LMM). Gaussian (normal) distribution was applied therefore in both dependent variables the continual measurements were characterized by symmetric errors that were located in the sufficient distance from the logical limits (from zero). Both models have used the following independent variables: time of storing (A/B), type of cheese (non-smoked/smoked), size of dairy producer (small/medium size), and their interactions. Random factor reflected data correlation in replicated measurements in each cheese within each locality (locality/cheese/measurement). Random factor 
also allowed random variability of individual slopes versus population slopes for individual differences in time (A/B). In both cases it was necessary to reflect and include an account for heteroskedasticity between the measurements in a different time (A/B). Analysis of salt required also heteroskedasticity between size of dairy producers (small/medium). Both models were fitted with a restricted maximum likelihood (REML) approach. The level of significance was set to $p<5 \%$.

\section{RESULTS}

To produce a stable and sensory attractive cheese there should be monitoring performed many physicochemical, sensory, and microbiological analysis during the production according to the HACCP regulations. Among others, the $\mathrm{a}_{\mathrm{w}}$ value and salt content measurement.

In the context of the above, two parameters - salt content and water activity were measured in smoked and non-smoked Parenica cheese immediately after sampling from 8 dairies (A) and subsequently after 7 days of storage (B) in the packed state at $4{ }^{\circ} \mathrm{C}$.

The results of salt content as well as water activity in fresh Parenica cheeses are presented in Table 2.

The higher content of $\mathrm{NaCl}$ was found in fresh Parenica cheese from small farms (non-smoked: $2.51 \pm 1.12 \mathrm{~g} / 100 \mathrm{~g}$, smoked: $1.97 \pm 0.89 \mathrm{~g} / 100 \mathrm{~g})$. The average salt content in cheeses from industrial dairies was $1.65 \pm 0.34 \mathrm{~g} / 100 \mathrm{~g}$ (non-smoked) and $1.96 \pm 0.43 \mathrm{~g} / 100 \mathrm{~g}$ (smoked). Results showed lower variability of salt content in cheeses from industrial dairies.

In our research differences in salt content between dairy producers were mainly in producer no. 5 with the highest overall values of salt content, and in producer no. 7 with the lowest (Figure 1). Except for producer no. 6, we can see general higher salt content in nonsmoked cheeses.

From the variability perspective (Figure 2), we can see a higher inconsistency of fresh, non-smoked cheeses in producer no. 7 and lowest in no. 4. After 7

Table 2. Salt content and water activity of fresh non-smoked and smoked Parenica cheeses from Slovak dairies

\begin{tabular}{|c|c|c|c|c|c|c|}
\hline Parameter & Dairy & Cheese sample & Min. & Max & Mean \pm SD & cv (\%) \\
\hline \multirow{3}{*}{$\begin{array}{c}\mathrm{NaCl} \\
(\mathrm{g} / 100 \mathrm{~g})\end{array}$} & \multirow{2}{*}{ small (farm) } & non-smoked & 0.75 & 4.52 & $2.51 \pm 1.12$ & 44.62 \\
\cline { 2 - 7 } & \multirow{2}{*}{ medium (industrial) } & smoked & 0.50 & 4.04 & $1.97 \pm 0.89$ & 45.17 \\
\cline { 3 - 7 } & \multirow{2}{*}{ small (farm) } & non-smoked & 1.03 & 2.60 & $1.65 \pm 0.34$ & 20.61 \\
\cline { 3 - 7 } & \multirow{3}{*}{ aw } & smoked & 1.21 & 3.62 & $1.96 \pm 0.43$ & 21.94 \\
\cline { 3 - 7 } & \multirow{2}{*}{ medium (industrial) } & non-smoked & 0.917 & 0.975 & $0.956 \pm 0.02$ & 2.09 \\
\cline { 3 - 7 } & & smoked & 0.911 & 0.975 & $0.943 \pm 0.02$ & 2.12 \\
\cline { 3 - 7 } & & non-smoked & 0.910 & 0.971 & $0.960 \pm 0.02$ & 2.08 \\
\hline
\end{tabular}

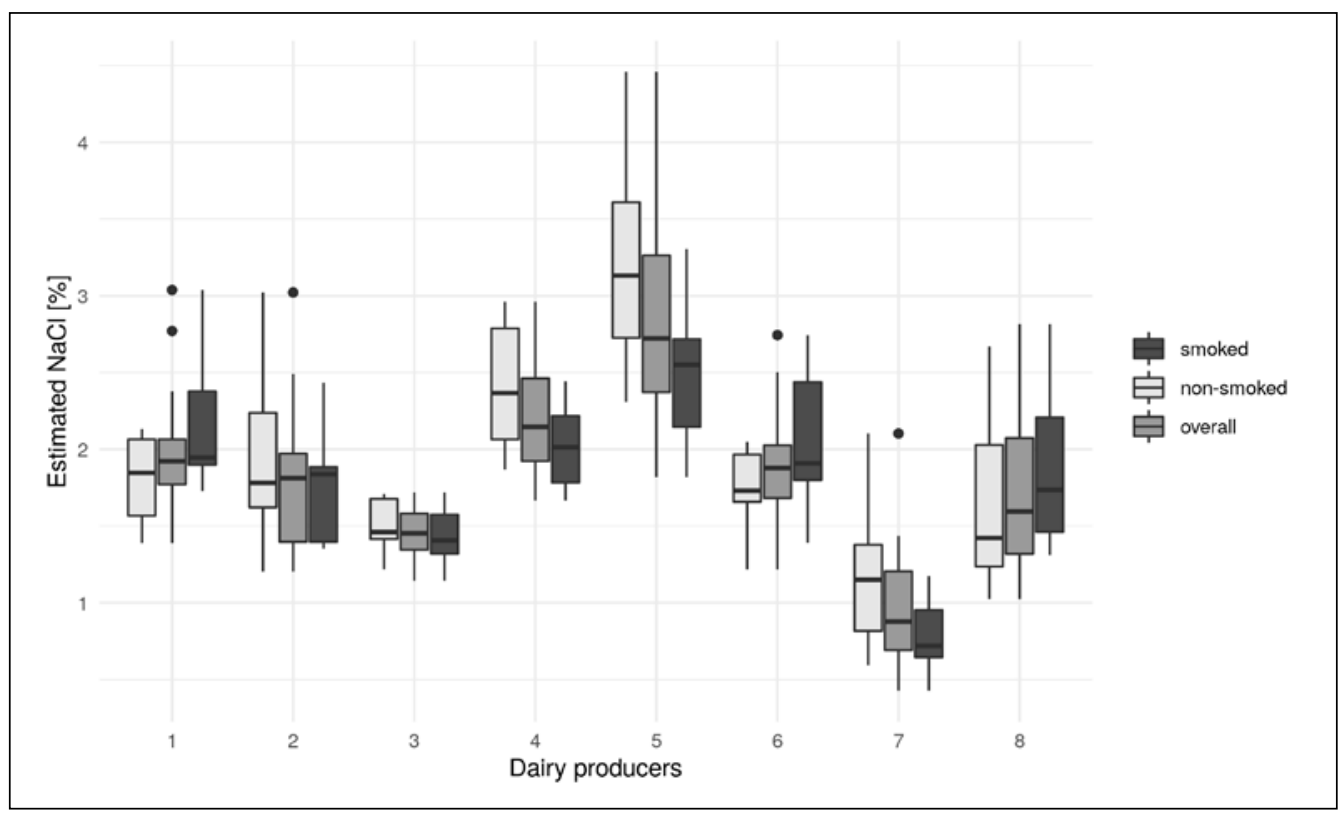

Figure 1. Distribution (median with the 25 th and 75 th percentiles) of salt content values in measured Parenica cheeses for smoked, non-smoked and overall (smoked+nonsmoked) per every dairy producers 
days of measurements, was the highest variation in no. 8. For smoked kinds was variation relative consistent, except for extreme small variation in fresh samples from producer no. 2. Heteroscedasticity between $\mathrm{A}$ and $\mathrm{B}$ was found in the small cheesemakers in comparison with the medium ones.

Generalized results from LMM showed significant differences between the main effect of the storing (fresh cheese A vs. stored B) $\left(\mathrm{F}_{1}=11.89 ; p=0.0010\right)$ as well as interaction between measurements in different storage length and type of cheesemaker (small/medium producer) $\left(\mathrm{F}_{1}=6.51 ; p=0.013\right)$ and interaction between measurements in different storage length and type of cheesemaker and type of cheese (smoked/non-smoked) $\left(\mathrm{F}_{2}=5.95 ; p=0.0041\right)$. What suggests that the salt content is changing depending on all three factors.

The overall mean content of $\mathrm{NaCl}$ after storing (B) is lower than in fresh samples (A) by 0.704 unit per $1 \% \mathrm{NaCl}$. This global decline can be seen in all categories except non-smoked cheeses from mediumsize producers (Figure 3).

The water activity of smoked Parenica cheese ranged from 0.908 to 0.975 and of non-smoked from

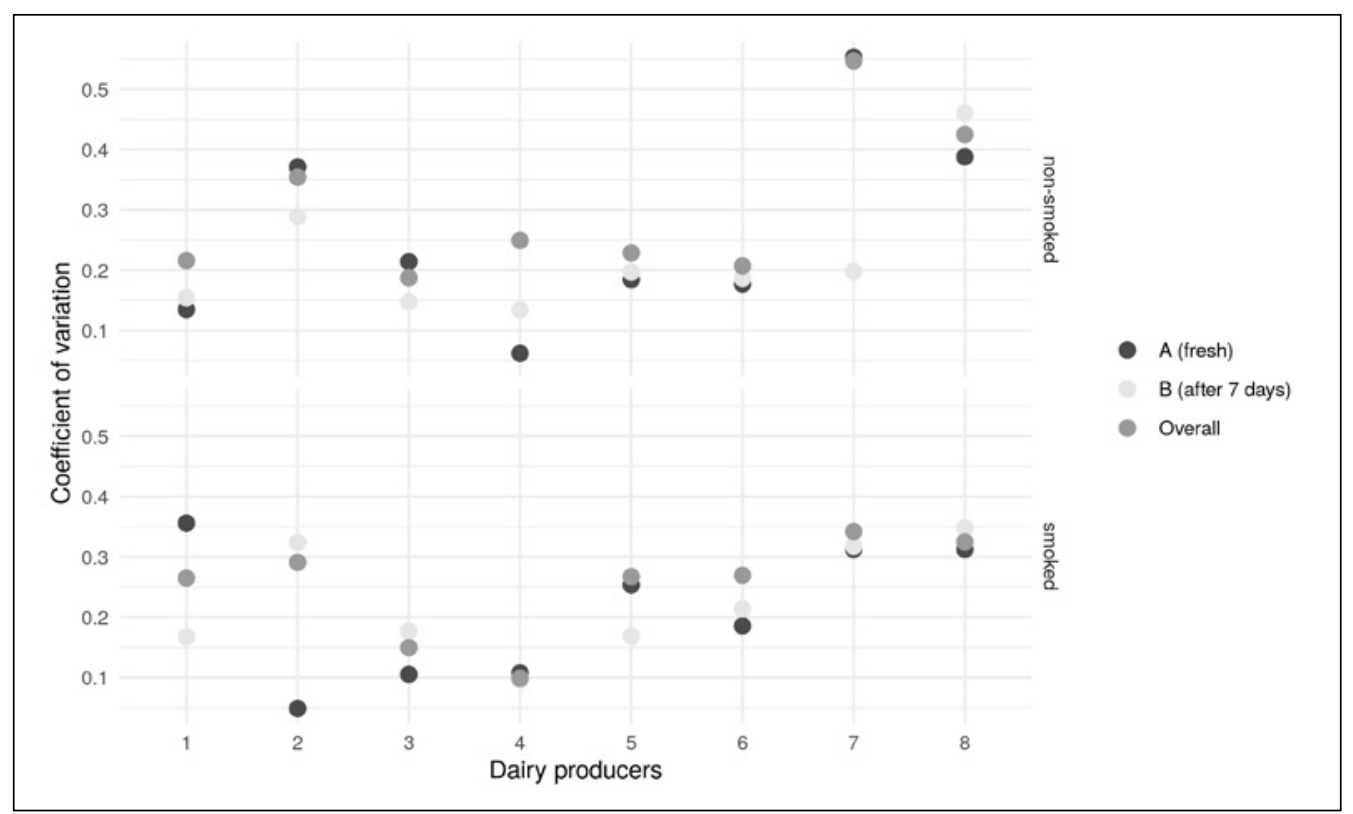

Figure 2. Variability of salt content values in measured Parenica cheeses for fresh (A), after 7 days storing $(\mathrm{B})$ and overall $(\mathrm{A}+\mathrm{B})$ per dairy producers

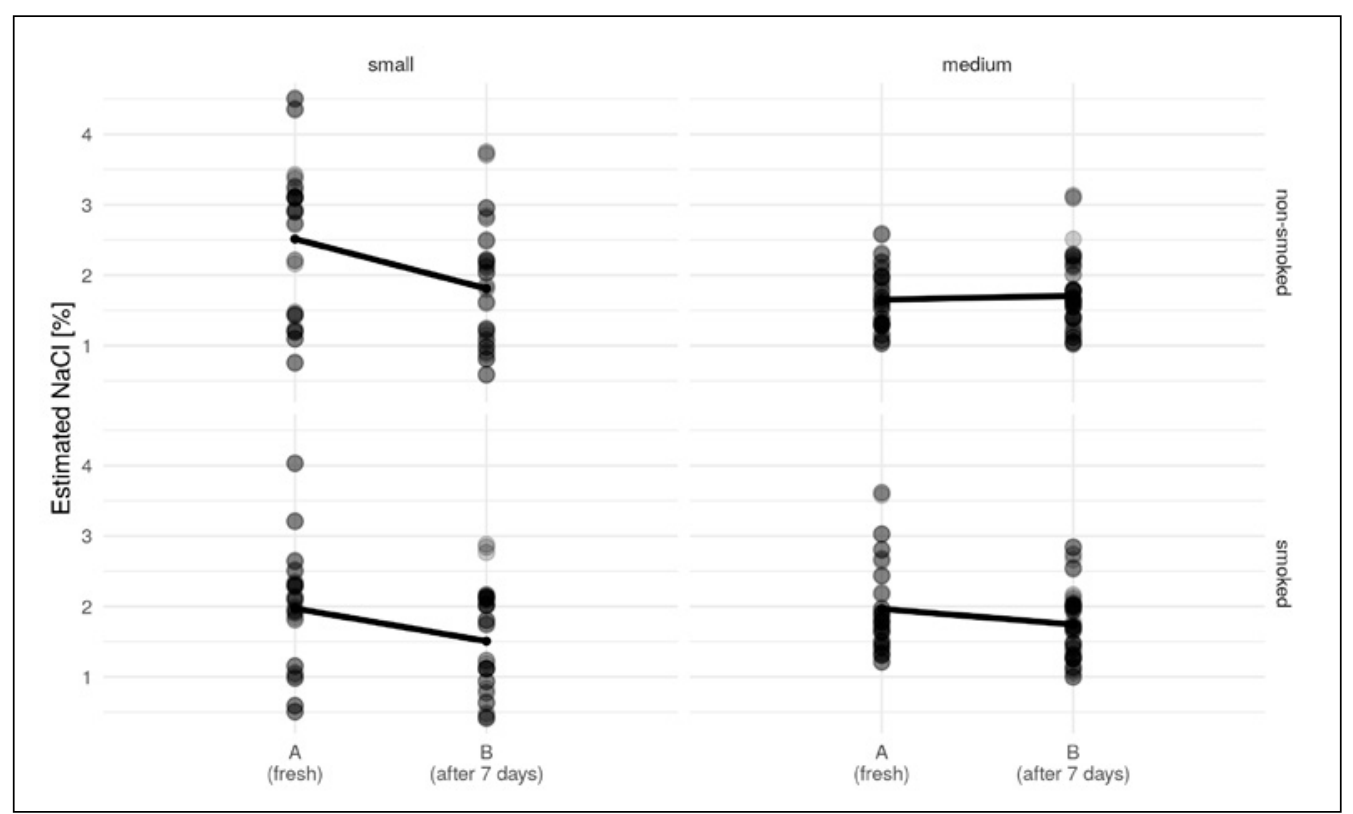

Figure 3. Salt content values with marginal mean differences between fresh (A) and after 7 days storing (B) for smoked and non-smoked Parenica cheeses depending on the producer size (small/medium) 
0.910 to 0.975 . The mean value of water activity in non-smoked Parenica cheeses taken directly (A) from small dairies was $0.956 \pm 0.02$. A slightly higher value was found in cheeses from the medium dairies $(0.960$ \pm 0.02 ). The values of the coefficients of variation were also comparable (2.09 and 2.08\%). In smoked versions of cheese were found slightly lower values of water activity $(0.943 \pm 0.02-$ small dairies and $0.969 \pm 0.01$ - medium dairies). Differences in water activity $\left(\mathrm{a}_{\mathrm{w}}\right)$ between small and medium-size dairy producers were not significant $(p>0.05)$, however, small variability was observed. The lowest water activity values were found in the cheeses from the dairy producer no. 2 and the highest $\mathrm{a}_{\mathrm{w}}$ had cheeses from the producers no. 3 and 7 (Figure 4). There is also an overall higher value of $a_{w}$ in non-smoked cheeses.

From Figure 5 we can see that variability depends not only on the dairy producer, but also on the type of Parenica cheese (smoked; non-smoked) and its freshness $(\mathrm{A} ; \mathrm{B})$.

In the case of smoked, fresh cheese was the highest variability observed in producer no. 7 and the lowest in no. 5 and 3. In, after 7 days measurements (B), were most inconsistency in producer no. 6 and least in no. 3 .

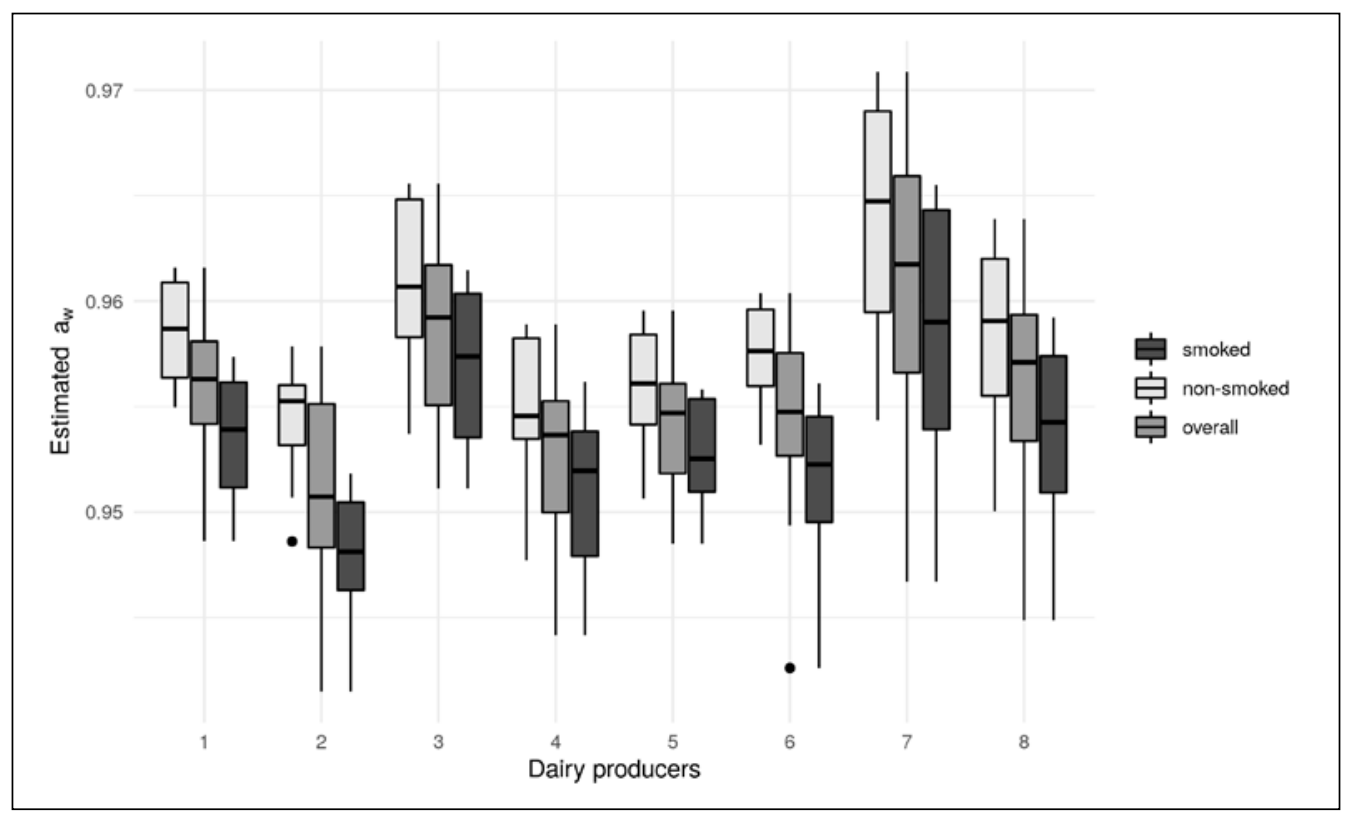

Figure 4. Distribution (median with the 25 th and 75 th percentiles) of water activity values in measured Parenica cheeses for smoked, non-smoked and overall (smoked+nonsmoked) per every dairy producers

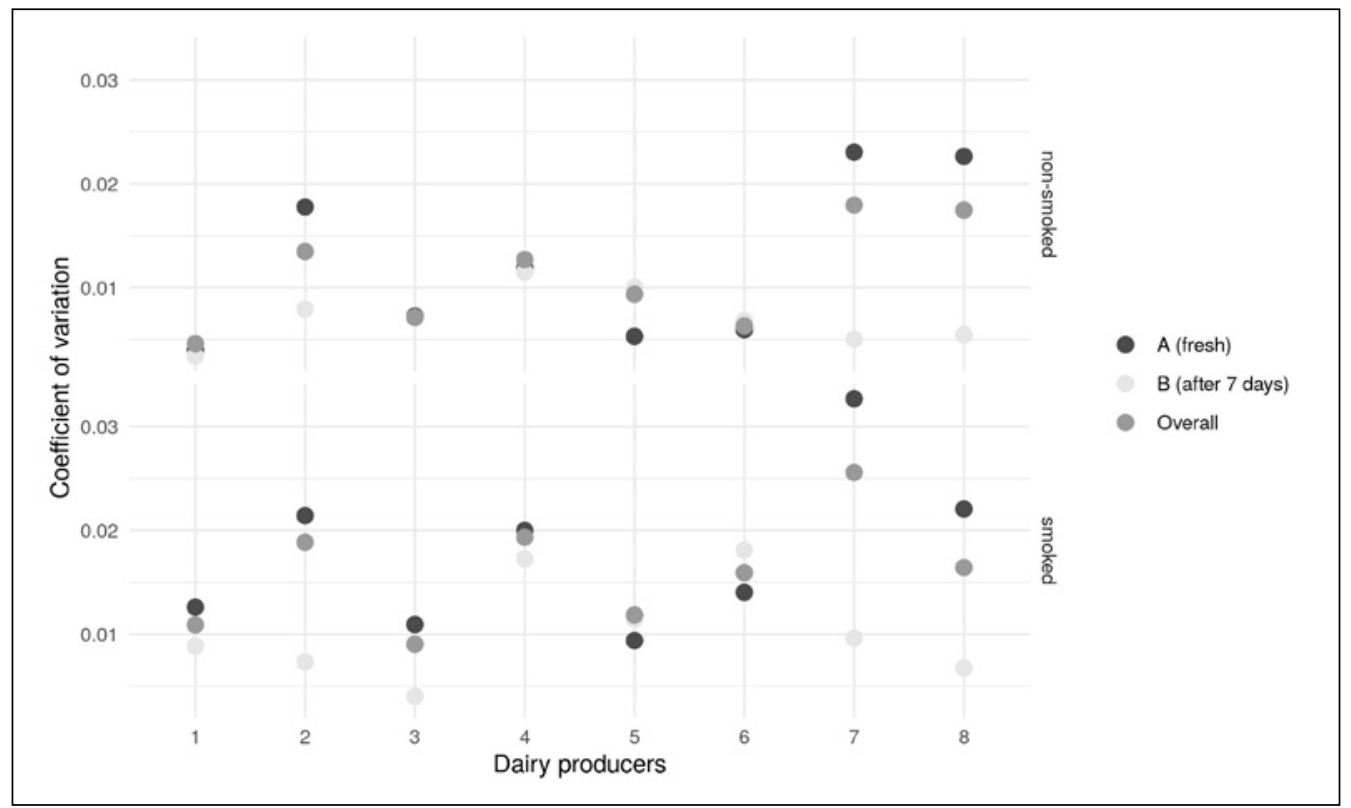

Figure 5. Variability of water activity values in measured Parenica cheeses for fresh (A), after 7 days storing (B) and overall $(\mathrm{A}+\mathrm{B})$ per dairy producers 
For non-smoked, fresh cheese, we can see the highest variability in no. 7 and 8 and lowest in no. 1. After 7 day's measurements (B), was the highest variability in no. 4 and lowest again in producer no 1 .

Overall consistency (showing the smallest differences between fresh and 7 days old Parenica cheese) was the highest in producer no. 1, for nonsmoked and no. 3 for smoked cheese. Contrariwise highest overall variability was in no. 7 for smoked and non-smoked cheese.

From Figure 5 we can also see an obvious general decline in variation between fresh and 7 days old cheese, except producers no. 5 and 6 , were on the contrary variability in increases.

After accounting for variations between dairy producers and heteroskedasticity between freshness, result from LMM showed a significant general increase between samples $\mathrm{A} / \mathrm{B}\left(\mathrm{F}_{1}=6.5 ; p=0.0129\right)$ and between kinds of Parenica cheese $\left(\mathrm{F}_{1}=5.7, p=\right.$ 0.0196) (Figure 6).

The overall mean of water activity in B samples is by 0.0059 higher than in A samples and by 0.0046 higher for non-smoked samples than for smoked. Although an interaction between these variables was not significant, we can suggest slightly higher values of water activity after 7 days, rather in smoked Parenica cheese than in non-smoked.

Dependence between the water activity and the salt content showed to be antagonistic. With increasing, salt content decreased water activity values approximately by decreased 0.0038 unit per $1 \%$ of $\mathrm{NaCl}$.

\section{DISCUSSION}

The quality of the traditional product may be different from farm to farm and dairies [44]. This claim is in line with the results published in similar studies in which there were significant differences in traditional product quality detected Čuboň et al. [7].

Measurement of the salt content of cheese is an important quality control step in cheese production. In cheese making, salt is highly relevant due to several factors, including microbiological control through the reduction of water activity, participation in cheese syneresis and mineral balance, regulation of biochemical processes, and contribution to taste [34].

Salt content is limited by the legislation of the Slovak Republic to $2.5 \mathrm{~g} / 100 \mathrm{~g}$ [35]. Each manufacturer in our research declared on the packaging label the dry matter, fat, and salt content. The most manufacturers reported a salt content of max. $2 \%$ (Table 1). The Parenica cheeses from two small dairy producers exceeded the declared values of salt content as a whole during the entire experimental period. $33 \%$ of the nonsmoked cheeses and $25 \%$ of smoked cheeses were in accordance with data declared on the package.

The variation of the salt content of the nonsmoked Parenica cheeses from small producers can be explained as follows. In industrial dairies, milk is standardized in fat content, the process of acidification of the curd is controlled by $\mathrm{pH}$ measurement. In this way, it is possible to ensure a more or less constant value of dry matter content or very low variation in dry matter content. The production of the cheese is continuous and thoroughly controlled. After the steaming, the curd is pulled mechanically, by

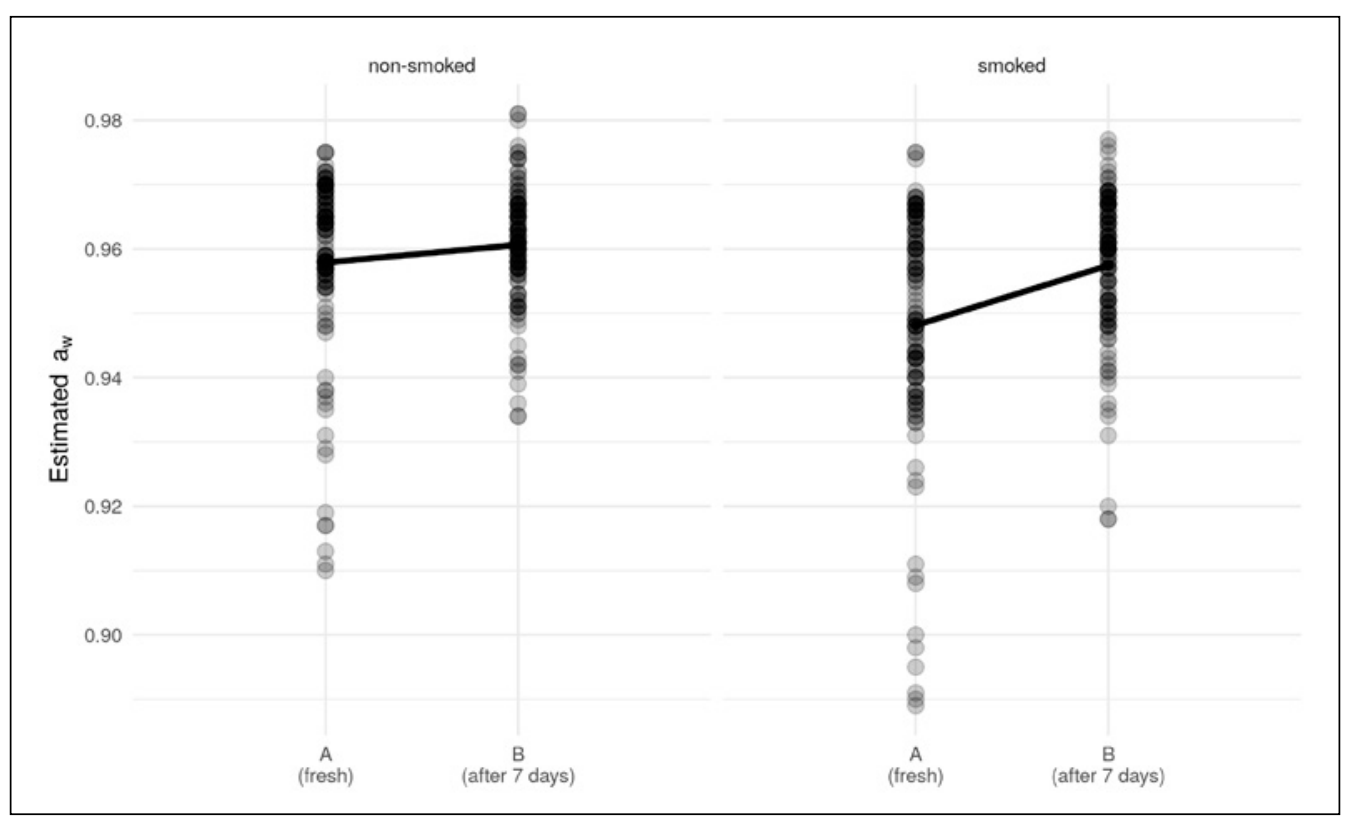

Figure 6. Water activity values with marginal mean differences between fresh (A) and after 7 days storing (B) for smoked and non-smoked Parenica cheeses 
machine, and pass through the brine in which the salt content is always adjusted before the processing. As the production is machine-made, the cheese is in brine for the same time.

In the case of farmer's Parenica cheeses, the milk is not standardized before the production, which means that during the year the cheese has a fat-varying content, which is also reflected in the dry matter variation. Obviously, the fatter parenica cheeses may have lower water content and hence the salt content will vary in such cheeses. The curd is steamed and pulled by hands and put in the brine bath where the cheese is also cooled. Farmers usually do not have special hydrometers to adjust the salt content of the brine, so they prepare the brine intuitively. This results in the fact that the cheese does not usually have a constant salt content and that is also the reason for the variation of the salt content. In the case of smoked cheese, other factors that cause variations in the quality of the cheeses are taken into account.

In industrial dairies, they have a smoke chamber equipped with a generator of the smoke that is subsequently blowing and circulating into the chamber where the cheeses are placed on the grates. During the controlled process, the temperature and smoking time can be adjusted and maintained. This is also reflected in the colour of the smoked cheese, which is uniform. While this method of smoking also increases dry matter, our measurements also show that the change in dry matter varies minimally. In addition to one of these dairies, Ducková et al. [8] found that the increase in dry matter is not statistically significant.

In farm production, cheeses are smoked in chambers without a smoke generator and usually do not have temperature and smoking time regulators. This explains why some Parenica cheeses were smoked more and some less. Another factor is that they do not control the temperature. As a result of higher temperatures, more fat is released from the cheeses, which of course must also be reflected in the dry matter. The salt that is water-soluble, is not removed with fat, and regarding this fact, the cheese of these producers is saltier.

The steamed cheeses may be salted during the steaming process (a hot salt solution is used as the steaming water), the salt may be added to the steamed dough at the exit of the steaming machine or cheeses may be salted in a cold salt bath, to keep their shape $[43,47]$.

When large amounts of salt are added to curd during cheese manufacture, the ability of starter bacteria to metabolize lactose to lactic acid is impaired, which would also contribute to stabilizing the cheese $\mathrm{pH}$ [31].

In the research of Estrada et al. [18] was found that the whole cheese reached a homogeneous salt distribution at 180 days of ripening. Brining conditions did not have an influence on the rate of salt penetration, but on the final sodium chloride $(\mathrm{NaCl})$ content. Cheese with higher salt content (3\%) showed increased proteolysis and lipolysis as compared to cheese with lower salt content (2.2\%).

Ducková et al. [8] analysed Parenica cheeses from farm dairy and found that no samples of non-smoked parenica cheese and only $33.3 \%$ of smoked Parenica cheeses were in accordance with a declared salt content of $2 \%$. The mean value of salt content was in nonsmoked cheeses $3.12 \pm 0.73 \%$ and in smoked cheeses $2.62 \pm 0.73 \%$. However, the coefficient of variation for both sample types was relatively high $(23.44 \%$ and $27.85 \%$, respectively).

On the contrary, Malová et al. [28] stated that the Slovak samples of smoked and non-smoked steamed cheeses were in accordance with the content of salt declared by the producer on the package and their contents ranged from $1.5 \%$ to $2.5 \%$.

The maximum limit of $\mathrm{NaCl}$ content of $3 \%$, which is stated in the national specification of traditional Slovenská Parenica, is published by the Industrial Property Office of the Slovak Republic and Official Journal of European Commission [10, 26]. It is important to note that our cheeses were made from cow milk - without trade name Slovenská.

Čubon [6] found that the $\mathrm{NaCl}$ content in traditional Slovak steamed-formed Parenica cheese made from lump cheese was $1.82 \pm 0.42 \%$ (after 1st week of maturing) and $1.58 \pm 0.28 \%$ (after 3 rd week of maturing).

Compared to other traditional cheeses produced in Slovakia, the salt content of traditional Parenica cheese is lower. The $\mathrm{NaCl}$ content of traditional Slovenský oštiepok cheese was $2.85 \pm 0.96 \%$ and in traditional Slovenský korbáčik cheese after the first week of cheese ripening it was $3.78 \pm 0.33 \%$ and after the second week of cheese ripening it was $2.93 \pm 0.76 \%$ [44].

Sodium chloride is traditionally added to cheeses as a preservative and to improve flavor. However, there is considerable evidence that high salt (sodium chloride) intake has been linked to health complications [2, 17, 20]. For these reasons, it is necessary to regularly monitoring whether food producers comply with the legal limits set for the application of salt in food production.

There are two ways to influence water activity. The water content, more specifically the amount of "free" water, and the amount of solutes can be controlled to a great extent by the cheesemaker. The further factors to set the water content are such as syneresis, the course of acidification, and the structure of curd grain [41].

As was studied from various sources [21, 23, 34] cheese varieties have typical values of $a_{w}$. During the cheese production, the $a_{w}$-value and salt content 
must be carefully considered for optimal cheese quality. For most cheese varieties, the salt to moisture ratio is the most important and easy to control parameter to influence the water activity [29].

It is well documented that pathogens grow more easily in cheese with higher moisture, high $\mathrm{pH}$, and low salt content [42]. Milk enzymes and starter cultures gradually hydrolyse milk compounds and lower the water activity. Such transformations are relatively small in fresh and soft cheese but very distinctive in semi-hard and hard cheese. The treatment with salt and the loss of water during the storage have an additive effect to lower the water activity [46].

Influence of $\mathrm{NaCl}$ on the water activity $\left(\mathrm{a}_{\mathrm{w}}\right)$ of cheese was studied by many other authors as Roos [39], McSweeney [32], McSweeney [33], McCarthy et al. [30], Hanauer et al. [22], McSweeney [34], Estrada et al. [18], etc.

\section{CONCLUSIONS}

Production of traditional cheese specialties in Slovakia is not negligible. The methods of milk processing have developed and changed considerably. Today, cheeses are produced in large quantities on automatic production lines in dairies and these products have balanced quality and product safety is regularly monitored. However, small-scale production continues in small farms, private dairies, or households where they have their own milk obtained from livestock. It is retail companies - small dairies - that produce most of the national cheese specialities, such as Slovenská bryndza, Slovenský oštiepok, or Slovenská parenica.

Our results of the salt content lead to the assumption that more frequent problems with maintaining of salt content were found in Parenica cheeses produced in small dairies. Higher salt content can have a negative effect on the health of consumers. Dependence between the water activity and the salt content showed to be antagonistic. With increasing, salt content decreased water activity values approximately by decreased 0.0038 unit per $1 \%$ of $\mathrm{NaCl}$.

The results showed that measuring the physicalchemical parameters during the cheese-making process is important for the product of standard quality. It can be concluded that especially the small producers can have probably problem in noncompliance with the technological processes, non-implementation of standardized procedures and underestimation of hygiene regulations.

All establishments, irrespective of capacity and produced range, must meet the basic requirements of the so-called "Hygiene package" of the European Union. They must comply with the legal regulations in the field of technological milk processing and must not underestimate the regular control of quality and hygiene-health parameters. The Association of Sheep and Goat Breeders in Slovakia has developed a hygiene manual based on HACCP principles for small producers which contain technological procedures for the production of these traditional products. A lot of training activities should be performed by government or professional associations focused on ensuring traditional cheese production.

\section{Conflict of interest}

The authors declare no conflict of interests.

\section{Acknowledgment}

This work was supported by the Slovak Research and Development Agency on the basis of Contract no. APVV-16-0244 "Qualitative factors affecting the production and consumption of milk and cheese".

\section{REFERENCES}

1. Abd El-Salam MH, Alichanidis E.: Cheese varieties ripened in brine. Major Cheese Groups. 2004: 227-249. Elsevier. https://doi.org/10.1016/s1874-558x(04)80046-0

2. Bansal V., Mishra SK.: Reduced-sodium cheeses: Implications of reducing sodium chloride on cheese quality and safety. Comprehensive Reviews in Food Science and Food Safety 2000; 19 (2): 733-758. https:// doi.org/10.1111/1541-4337.12524

3. Bähler B., Kunz A., Hinrichs J.: Hot brining of pasta filata cheese: effect of sodium and calcium chloride on composition, yield, and hardness. Dairy Science \& Technology 2016; 96 (5): 703-714. https://doi. org/10.1007/s13594-016-0299-9

4. Costa RGB, Alves RC, Cruz AG, da Sobral D., Teodoro VAM, Costa Junior LCG, Paula, J. C. J. de, Landin, T. B., Miguel, E. M. : Manufacture of reduced-sodium Coalho cheese by partial replacement of $\mathrm{NaCl}$ with $\mathrm{KCl}$. International Dairy Journal 2018; 87: 37-43. https://doi. org/10.1016/j.idairyj.2018.07.012

5. Coulon JB., Delacroix-Buchet A., Martin B., Pirisi $A$ :: Relationships between ruminant management and sensory characteristics of cheeses: a review. Le Lait 2004; 84 (3): 221-241. https://doi.org/10.1051/ lait:2004008

6. Čuboň $J$.: The effect of raw material pre maturing on Parenica steamed cheese quality. Journal of Microbiology, Biotechnology and Food Sciences 2019; 8 (5): 1231-1235. https://doi.org/10.15414/ jmbfs.2019.8.5.1231-1235

7. Čuboň J., Kunová S., Kačániová M., Haščík P., Bobko M., Bučko O., Petrová J., Cviková P.: Quality evaluation of Korbačik cheese. Potravinarstvo - Slovak Journal of Food Sciences 2015; 9 (1): 523-529. https://doi. org/10.5219/549

8. Ducková V., Čanigová M., Zeleňáková L., Kročko M.: Changes in selected parameters of steamed cheese during storage. J. Microbiol. Biotech. Food Sci. 2020;9(5):10161019. https://doi.org/10.15414/jmbfs.2020.9.5.1016-1019 
9. Dudriková E.: Hygienic and Technological Aspects of the Collection and Processing of Sheep's Milk in the Mountain Conditions in Slovakia, 1st ed., 2011: 21. Košice: University of Veterinary Medicine and Pharmacy in Košice.

10. EC. Council Regulation (EC) No 510/2006 on the protection of geographical indications and designations of origin for agricultural products and foodstuffs. Publication of an application pursuant to Article 6(2) of Council Regulation (EC) no 510/2006. Council Regulation (EC) No 510/2006 of 20 March 2006 on the protection of geographical indications and designations of origin for agricultural products and foodstuffs OJ L 93, 31.3.2006, p. 12-25.

11. EC. Publication of an application pursuant to Article 6(2) of Council Regulation (EC) No 510/2006 on the protection of geographical indications and designations of origin for agricultural products and foodstuffs. OJ C 249, 24.10.2007, p. 26-30.

12.EC. Commission Regulation (EC) No 656/2008 of 10 July 2008 registering certain names in the Register of protected designations of origin and protected geographical indications (Chamomilla Bohemica (PDO), Vlaams-Brabantse tafeldruif (PDO), Slovenská parenica (PGI), Cipollotto Nocerino (PDO)) OJ L 183, 11.7.2008, p. 15-16.

13. EC. Commission Regulation (EC) No 943/2008. Commission Regulation (EC) No $943 / 2008$ of 25 September 2008 entering certain names in the Register of protected designations of origin and protected geographical indications (Presunto de Campo Maior e Elvas or Paleta de Campo Maior e Elvas (PGI), Presunto de Santana da Serra or Paleta de Santana da Serra (PGI), Slovenský oštiepok (PGI)) OJ L 258, 26.9.2008, p. 52-53.

14. EC. Commission Implementing Regulation (EU) No 243/2011 of 11 March 2011 entering a name in the register of protected designations of origin and protected geographical indications (Oravský korbáčik (PGI)) OJ L 66, 12.3.2011, p. 19-20.

15. EC. Commission Implementing Regulation (EU) No 238/2011 of 11 March 2011 entering a name in the register of protected designations of origin and protected geographical indications (Zázrivský korbáčik (PGI)) OJ L 66, 12.3.2011, p. 9-10.

16. El Soda M., Abd El-Salam MH: CHEESE | Cheeses Matured in Brine. In Encyclopedia of Dairy Sciences 2002: 406-411. https://doi.org/10.1016/b0-12-2272358/00082-1.

17. Elias M., Laranjo M., Cristina Agulheiro-Santos A., Eduarda Potes M.: The Role of Salt on Food and Human Health. Salt in the Earth. 2020. IntechOpen. https://doi. org/10.5772/intechopen.86905.

18. Estrada O., Ariño A., Juan T.: Salt Distribution in Raw Sheep Milk Cheese during Ripening and the Effect on Proteolysis and Lipolysis. Foods 2019;8(3):100. https:// doi.org/10.3390/foods8030100.

19. Everett DW, Auty MAE: Cheese structure and current methods of analysis. International Dairy Journal 2008;18 (7):759-773. https://doi.org/10.1016/j. idairyj.2008.03.012.
20. Farquhar WB, Edwards DG, Jurkovitz CT, Weintraub WS: Dietary Sodium and Health. Journal of the American College of Cardiology 2015;65(10):10421050. https://doi.org/10.1016/j.jacc.2014.12.039.

21. Guinee TP, Fox PF: Salt in Cheese: Physical, Chemical and Biological Aspects. In Cheese: Chemistry, Physics and Microbiology 2004: 207-259. Elsevier. https://oi. org/10.1016/s1874-558x(04)80069-1.

22.Hanauer DC, Rigo E., Bagatini L., Steffens J., Cavalheiro $D$.: Influência da substituição parcial de cloreto de sódio por cloreto de potássio em queijo minas frescal de leite de ovelha. Revista Do Instituto de Laticínios Cândido Tostes 2016; 71 (3): 119. https://doi.org/10.14295/22386416.v71i3.500.

23. Hardy J.: Water activity and cheese salting. In Cheese making from Science to Quality Assurance, 2nd ed., Eck, A. \& Gillis, J.C., eds, Lavoisier Publications, Paris. 2000: 60-81.

24.Herian K., Kerestě̌ J., Hrbek I. Cheese production, 2015: 1-79. http://www.smacr.cz/data/public/seminare/ Vyroba-syru-14.-a-15.1.2015_2.pdf.

25.Illescas-Chavez E., Vélez-Ruiz JF: Effect of the Salting Process on the Mass Transfer Kinetics of Manchego-type Cheese. International Journal of Food Properties 2009; 12 (4): 791-807. https://doi. org/10.1080/10942910802072983.

26.IPO SR. 2006. Specification. Slovak parenica. https:/www.indprop.gov.sk/swift_data/source/pdf/ specifikacie_op_oz/slovenska_parenica.pdf

27. Kerestě̌ J., Selecký J.: Cheese Production in Slovakia: History and Technologies. Považská Bystrica, Slovakia : Eminent. 2005: 368. ISBN 80-969387-9-7.

28. Malová J., Výrostková J., Semjon B., Dudriková E., Čopíková M.: The steamed cheeses in a border areas of Slovakia. In Proceeding of Food hygiene and technology XLVII. Lenfeld and Hökl days. Brno, Czech Republic : Veterinary and Pharmaceutical University, 2017: 183-186.

29. Marwade DH, Kanawjia SK., Khetra Y., Puri R., Debnath A., Gupta HR.: Changes in sensory and physico-chemical attributes of low sodium mozzarella cheese during storage. Indian Journal of Dairy Science 2017; 70 (6): 650-657.

30.McCarthy CM, Wilkinson MG, Kelly PM, Guinee TP: Effect of salt and fat reduction on the composition, lactose metabolism, water activity and microbiology of Cheddar cheese. Dairy Science \& Technology 2015; 95 (5): 587-611. https://doi.org/10.1007/s13594-015-0245-2.

31. McMahon DJ., Oberg CJ, Drake MA, Farkye N, Moyes LV, Arnold MR., Ganesan B, Steele J, Broadbent JR: Effect of sodium, potassium, magnesium, and calcium salt cations on $\mathrm{pH}$, proteolysis, organic acids, and microbial populations during storage of full-fat Cheddar cheese. Journal of Dairy Science 2014; 97 (8): 47804798. https://doi.org/10.3168/jds.2014-8071.

32. McSweeney PLH: Biochemistry of cheese ripening. International Journal of Dairy Technology 2004; 57 (2-3): 127-144. https://doi.org/10.1111/j.14710307.2004.00147.x 
33. McSweeney PLH: Cheese problems solved. Boca Raton, FL, USA: CRC Press and Woodhead Publishing Limited. 2007. https://doi.org/10.1533/9781845693534.

34.McSweeney PLH, Fox PF, Cotter PD, Everett DW: Cheese: chemistry, physics and microbiology (4th edn.). London, UK: Elsevier Academic Press. 2017.

35. MH SR: Ministry of Health of the Slovak Republic. Decree No. S08975-OL-2014 laying down requirements for edible salt in foodstuffs. Journal of the Ministry of Health of the Slovak Republic 2015; 61 (10-11): 50-57.

36. Onipchenko N., Doležalová M., Prochádzková E., Martinková I., Hrabě J.: Microflora changes during steam production. (Změny mikroflíy behěm výroby pařených). Mlékařské listy 2012; 132: 4 (In Czech) http://www.mlekarskelisty.cz/pdf/2012/132_s._i-iv.pdf.

37. Pinheiro J., Bates D., Debroy S., Sarkar, D.: R Core Team nlme: Linear and Nonlinear Mixed Effects Models. R package version 3.1-137, 2018. https://CRAN.R-project. org $/$ package $=$ nlme

38. $R$ Core Team: R: A language and environment for statistical computing. R Foundation for Statistical Computing, Vienna, Austria. 2018. https://www.Rproject.org/.

39. Roos YH: Water in Milk Products. In Advanced Dairy Chemistry 1997; 3: 303-346). Springer US. https://oi. org/10.1007/978-1-4757-4409-5_8.

40.Santapaola J., Maldonado S., Medina JL: $\mathrm{NaCl}$ diffusion kinetics in dry salting of goat cheese. Journal of Food Engineering 2013; 118 (2): 172-177. https://oi. $\operatorname{org} / 10.1016 /$ j.jfoodeng.2013.03.028.

41. Simatos D., Multon JL: Properties of Water in Foods. Springer Netherlands. 1985. https://doi.org/10.1007/97894-009-5103-7.
42.Tripaldi C., Palocc, G., Giovanni S., di Marri N., Boselli C., Giangolini G., Amatiste S.: Microbiological and chemical characteristics of pasta filata type cheese from raw ewe milk, using thermophilic and mesophilic starters. Journal of Food Safety and Food Quality 2018; 69 (4): 105-130.

43. Walstra P., Wouters JTM, Geurts TJ: Dairy Science and Technology. 2nd edition. Boca Raton, FL: CRC/Taylor \& Francis, 2006: 808. ISBN 9780824727635.

44.Zajác P., Martišová P., Čapla J., Čurlej J., Golian J.: Characteristics of textural and sensory properties of Oštiepok cheese. Potravinarstvo - Slovak Journal of Food Sciences 2019; 13 (1): 116-130. https://doi. org/10.5219/855.

45.Zeleñáková L., Ševčík M., Jakabová S.: The water activity comparison in parenica cheeses from different producers in relation with a storage time. In proceeding of conference Food/Bio/Tech, Nitra, Slovakia. 1st ed. 2019: 85. Nitra, Slovakia : Slovak University of Agriculture in Nitra, ISBN 978-80-552-2038-3.

46.Zigerlig C.: Water control in cheese production Manager Marketing \& Verkauf, Novasina AG. 2020. https:// www.pedak.nl/pdf/a $\mathrm{a}_{\mathrm{w}} \% 20$ and-cheese-E.pdf.

47. Zimanová M., Greifová M., Body P., Herian K.: Technology of steamed cheese production (Technológia výroby parených syrov). Chemické Listy 2016; 110 (4): 258-262. www.chemickelisty cz/ojs3/index.php/ chemicke-listy/article/view/201.

Received: 21.05 .2020

Accepted: 01.07.2020 